九州大学学術情報リポジトリ

Kyushu University Institutional Repository

Chemosynthetic fossil molluscan faunas from the Neogene Taishu Group, distributed in Tsushima Islands, Nagasaki Prefecture, the southwest Japan

Ninomiya, Takashi

Department of Earth and Planetary Sciences, Graduate School of Science, Kyushu University

https://doi.org/10.5109/19194

出版情報: 九州大学大学院理学研究院紀要：Series D, Earth and planetary sciences. 32 (3)， pp.11-26, 2011-03-10. Faculty of Science, Kyushu University

バージョン：

権利関係 : 
Mem. Fac. Sci., Kyushu Univ., Ser. D, Earth \& Planet. Sci., Vol. XXXII, No. 3, pp. 11-26, March 10, 2011

\title{
Chemosynthetic fossil molluscan faunas from the Neogene Taishu Group, distributed in Tsushima Islands, Nagasaki Prefecture, the southwest Japan
}

\author{
Takashi Ninomiya*
}

\begin{abstract}
The middle of the Neogene Taishu Group, distributed in Tsushima Islands, Nagasaki Prefecture, the southwest Japan, is considered to include the authigenic carbonates originated from cold-seep and the chemosynthetic molluscan faunas deposited in deep sea environment of greater than $500 \mathrm{~m}$ depth. In this study, the author examined classification of the bivalves occurred in the middle of the Taishu Group. Consequently, the molluscan faunas are assigned into the following ten species belonging to seven genera: Bathymodiolus sp., Adipicola sp., Calyptogena spp., Acharax spp., Acila sp., Nuculana sp., and Yoldia sp.
\end{abstract}

Keywords: the Neogene Taishu Group, deep sea environment, chemosynthetic molluscan faunas

\section{Introduction}

The formation of the Sea of Japan is thought to be the results of the following processes. (1) The east margin of the Eurasian Continent subsided in the late Cenozoic; (2) the spreading of the Sea of Japan reached the climax opening stage in the Early Miocene; and (3) the Japanese Archipelago was formed in the middle Miocene (Otofuji and Matsuda, 1983, 1985). The Taishu Group distributed in Tsushima Islands, which is located in the southwest part of the Sea of Japan, has been regarded as the conformable marine deposits and they can be compared with the Paleogene strata distributed in the northwest Kyushu (Nakajo and Funakawa, 1996; Nakajo et al., 2006). Therefore, Tsushima Islands are important area in reconstructing the formation history of the Sea of Japan and the Japanese Archipelago. However, our knowledge concerning the sedimentary environments of the Taishu Group was fragmental and there are many unsettled discussions about the formation age (Okada and Fujiyama, 1970; Nakajo and Maejima, 1998; Nakajo et al., 2006; Yamaguchi and Oho, 2007). Furthermore, the maga-fossils found in the Taishu Group are of mainly shallow marine fossil faunas. However, the maga-fossils are scarce and poorly preserved (Matsumoto, 1969; Masuda, 1970; Takahashi and Nishida, 1975). The author has been studying about the Taishu Group distributed in Tsushima Islands to understand the formation processes of the Sea of Japan and the depositional environments of the deep sea sediments in the southwestern Sea of Japan. Recently, small-scale carbonate and fossil assemblages are found successively in the middle of the Taishu Group (Aoki and Nishida, 1999; Ninomiya et al., 2008). In our study, it has been shown that they are authigenic carbonates originated from cold-seep and that the fossil molluscan faunas are chemosynthetically formed (Ninomiya et al., 2008). They state that the middle of the Taishu Group was deposited in deep-sea environments at greater than $500 \mathrm{~m}$ depth (Ninomiya et al., 2010). Therefore, cold-seep carbonates and chemosynthetic fossil assemblages from the Taishu Group are important in deciphering the paleoenvironments of the opening stage of the Sea of Japan. The author reports the classification of chemosynthetic bivalves occurred from the Taishu Group in this paper.

Manuscript received on 24 December 2010; accepted on 27 January 2011

* Department of Earth and Planetary Sciences, Graduate School of Science, Kyushu University, Hakozaki6-10-1, Fukuoka, 812-8581, JAPAN; author's e-mail: sc308031@s.kyushu-u.ac.jp 


\section{Geological setting of Tsushima Islands}

Tsushima Islands are located at $120 \mathrm{~km}$ off Kyushu in the southwestern Sea of Japan (Fig. 1). The Taishu Group is conformable marine formation with the thickness of greater than 5,400 m and it is classified into the Lower Formation, Middle Formation and Upper Formation based on lithology and distribution of T3 Tuff (MITI, 1973). The layer of T3 Tuff can be tracked in distance of greater than $40 \mathrm{~km}$ (Fig. 2). Anticlinorium and synclinorium structures with a northeast-southwest axis are observed in Tsushima Islands. In the south of Tsushima Islands, where granite as intrusive rock is observed the Taishu Group was affected by contact metamorphism. Also observed are rhyolite, quartz porphyry, plagiophyre and dolerite as intrusive rocks. The formation age of the Taishu Group has been regarded as the early Eocene-early Miocene (Ibaragi, 1994; Nakajo and Funakawa, 1996; Sakai and Yuasa, 1998). However, the author and his colleagues dated T3 Tuff and subaqueous pyroclastics of the Upper Formation. Consequently, we learned that the main part of the Taishu Group was deposited at approximately $16 \mathrm{Ma}$ which was in the middle Miocene (Ninomiya et al., 2010). Furthermore, the lower most of the Taishu Group with the reported early Eocene radiolarians may be compared with the Paleogene strata distributed in the northwest Kyushu.

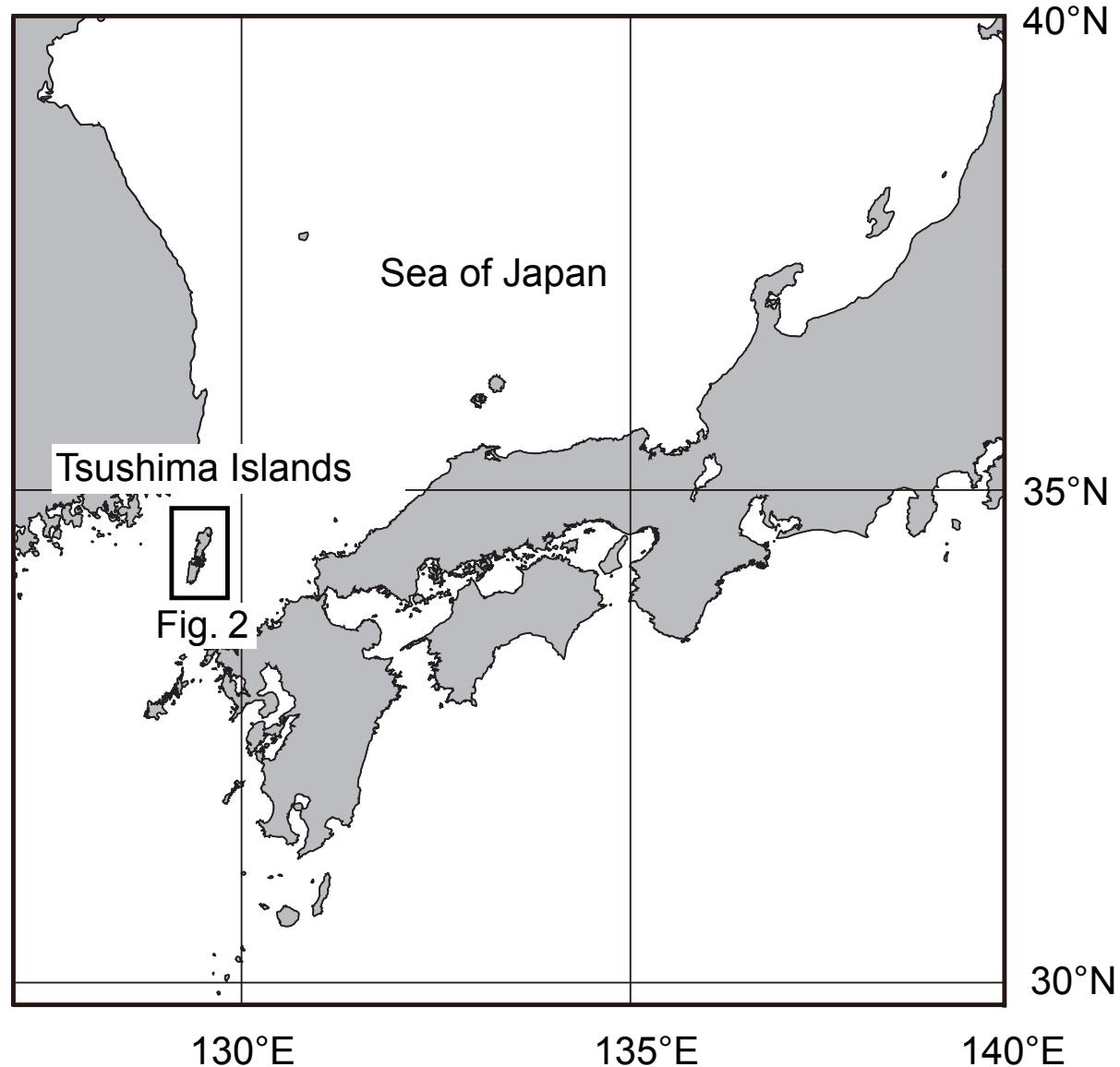

Fig. 1. Location of Tsushima Islands. 


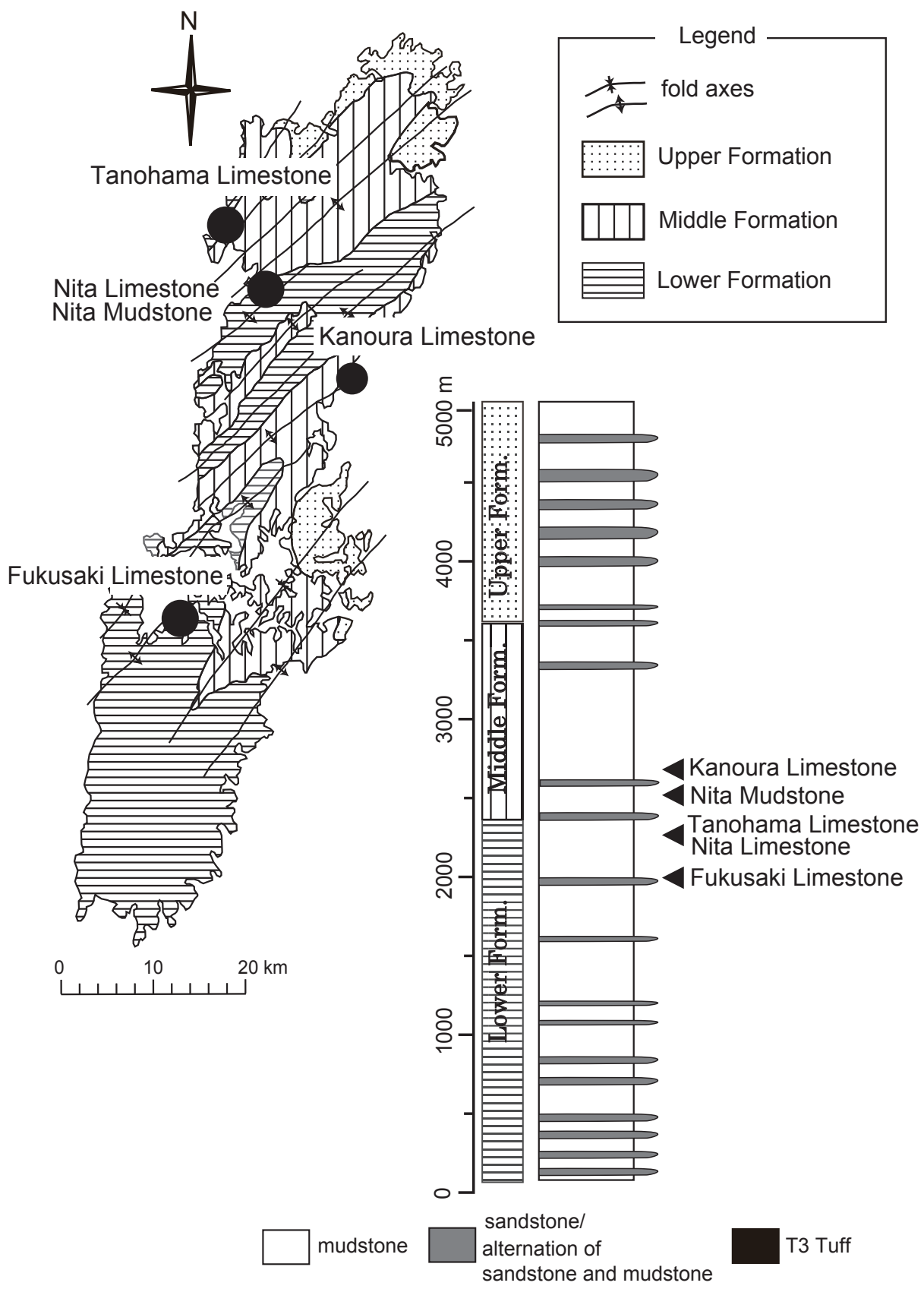

Fig. 2. Geologic map of Tsushima Islands and lithological column of the Taishu Group based on MITI (1972, 1973, 1974). Circles show the locality of limestone and chemosynthetic fossil assemblages.

\section{Chemosynthetic bivalves from the Taishu Group}

MITI (1972) reported Adulomya cf. uchimuraensis, Calyptogena akanudaensis from the limestone boulder at Tanohama, where the upper part of the Lower Formation is located. Aoki and Nishida (1999) found a lenticular limestone including small Adulomya sp. from the same horizon. Moreover, fossil molluscan faunas are dominated by Acharax spp. with occurrences of Sacella, Yoldia and Portlandia. These fossil molluscan faunas are quite dense in population and they are regarded as chemosynthetic fossil assemblages.

Ninomiya et al. (2010) reported that fossil assemblages of the authigenic cold-seep carbonates and mudstone are chemosynthetic bivalves which are mytilids, vesicomyids and solemyids. As Aoki and Nishida (1999) indicated, the calcareous shells are absent in mudstones but are preserved in carbonates. Based on these conditions, the middle part of the Taishu Group is considered to be deposited at deep-sea floor greater than $500 \mathrm{~m}$ depth (Ninomiya et al., 2010). 


\section{Description of molluscan fossils}

Class Bivalvia Linnaeus, 1758

Family Solemyidae Gray, 1840

Genus Acharax Dall, 1908

Type species: Solemya johnsoni Dall, 1891; Recent, Northeast Pacific.

\section{Acharax sp. A}

Plate 1, fig. 1

Acharax sp. A, Aoki and Nishida, 1999.

Locality: Nita (Basal part of the Middle Formation; Aoki and Nishida, 1999)

Measurements (in $\mathrm{mm}$ ) :

\begin{tabular}{ccccccccc}
\hline $\begin{array}{c}\text { Sumple } \\
\text { No. }\end{array}$ & valve & Length & La & Height & $\begin{array}{c}\text { Height/ } \\
\text { Length }\end{array}$ & La/L & $\begin{array}{c}\text { Rib } \\
\text { number }\end{array}$ & Plate \\
\hline Aok-001 & $\begin{array}{c}\text { right } \\
\text { balve }\end{array}$ & 49.7 & 14.2 & 23.7 & 0.48 & 0.29 & 20 & $\begin{array}{c}\text { Plate 1, } \\
\text { fig. 1 }\end{array}$ \\
\hline
\end{tabular}

La: Length of anterior margin.

Description: Shell is of middle size. Ligament external. Dorsal margin straight, antero-postero margin rounded. Ventral margin nearly straight. Umbo located at anterior one and third of valve of shell length. Radial ribs count 18-20, and marginal portion degitated beyond shell margin. The ribs are strong at anterior-posterior end, but weak and obscure at center of valve.

Remarks: According to Aoki and Nishida (1999), this species resembles Acharax tokunagai. As Sasaki et al. (2005) indicated, Solemya (Acharax) agasizii, Solemya tokunagai, Solemya (Acharax) tibai, and Solemya tokunagai elongata are synonymyzed with Solemya johnsoni (Coan et al., 2000). This species resembles Acharax johnsoni in many points. However, umbo of Acharax johnsoni situates posteriorly, 78\%. Therefore, this species may be distinguished from Acharax johnsoni.

\section{Acharax sp. B}

Plate 1, figs. 2-6

Acharax sp. B, Aoki and Nishida, 1999.

Locality: Nita (Basal part of the Middle Formation; Aoki and Nishida, 1999)

Measurements (in $\mathrm{mm}$ ) :

\begin{tabular}{ccccccccc}
\hline Sumple No. & valve & Length & La & Height & $\begin{array}{c}\text { Height/ } \\
\text { Length }\end{array}$ & La/L & $\begin{array}{c}\text { Rib } \\
\text { number }\end{array}$ & Plate \\
\hline Aok-002 & right balve & 38.3 & 8.8 & 13.8 & 0.36 & 0.23 & 17 & Plate 1, fig. 2 \\
GK-L12000 & left valve & 29.4 & 8.2 & 10.4 & 0.35 & 0.28 & 17 & Plate 1, fig. 3 \\
Aok-003 & right balve & 44.2 & 10.6 & 13.3 & 0.30 & 0.24 & $15+$ & Plate 1, fig. 4 \\
GK-L12001 & right balve & $59.5+$ & 16.1 & - & - & - & 18 & Plate 1, fig. 5, 6
\end{tabular}

Description: Shell is small to middle size and elongated. Ligament external. Dorsal margin straight, anteropostero margin rounded. Ventral margin nearly straight. Umbo located at anterior about three of quarter of valve length. Radial ribs count 17 , and marginal portion digitated beyond shell margin. The ribs are strong at anterior-posterior end, but weak and obscure at center of valve.

Remarks: Bivalves of geneus Acharax is reported at least in eight species (Baba, 1990; Hatai and Koike1956; Kamada, 1962; Kanehara, 1937; Kanno, 1960; Kanie and Kuramochi, 1995; Kanie et al, 1995; Kanie et al., 1999; Natori, 1964). This species resembles Acharax yessoensis, Acharax dalli, Acharax muroensis, and Acharax gigas. However, radial rib numbers of $A$. yessoensis are 18-20. Shell length of $A$. dalli is smaller than that of this species and radial rib numbers are 10-11. Shell length of $A$. muroensis is less than that of this species. Acharax bosoana is larger than Acharax sp. B and has 10-11 ribs. Shell size of Acharax gigas is much larger than those of $A$. yessoensis, A. dalli, A. muroensis and Acharax sp. B. Therefore, Acharax sp. B can clearly be distinguished from other species. It appears necessary in the future to discuss about the possibility of erecting this taxon as a new species.

Acharax sp. C

Plate 2, figs. 1-2

Locality: Kanoura (Lower part of the Middle Formation)

Description: Shell size and outline unknown. Ligament is external. Radial ribs marginal portion digitated beyond shell margin. Frequently, this species is observed in mudstones around Kanoura Limestone. However, shells are imperfect, shell outline is unknown. This species may be identified as Acharax sp. A or Acharax sp. B. In this paper, the author assigns this taxon as Acharax sp. C.

Class Bivalvia Linnaeus, 1758

Family Nuculidae Adams and Adams, 1858

Genus Acila Adams and Adams, 1858

Type species: Nucula divaricata Hinds, 1843; Recent, China

\section{Acila sp.}

Plate 2, fig. 3

Locality: mudstone around Fukusaki Limestone (Upper part of the Lower Formation) 
Measurements (in $\mathrm{mm}$ ):

\begin{tabular}{ccccc}
\hline Sample No. & valve & Length & Height & Plate \\
\hline \multirow{2}{*}{ GK-L12004 } & left valve & $26+$ & $34.7+$ & Plate 2, fig. 3 \\
\hline
\end{tabular}

Description: Shell length greater than $26 \mathrm{~mm}$ and height reaching about $35 \mathrm{~mm}$. Shell subovate, inequilateral, not so inflated well-defined rostral portion. Posterior side is very short. Umbo located at nearly posterior margin. Anterior dorsal margin gently sloping, but anterior end is absent. Ventral margin regularly arched. Posterior margin form and lunula cannot be observed. Sculpture consisting of divaricating oblique threads, the line of main devarication is slightly posterior to the middle.

Remarks: This species resembles Acila submirabilis and is common in the Neogene of Japan. However, umbo, linule and posterior margin forms are unknown. Therefore, the author tentatively assigns this taxon as Acila sp. until well-preserved specimens with visible structures are studied.

Family Nuculanidae Adams and Adams, 1858

Genus Nuculana Link, 1807

Type species: Arca rostrata Bruguière, 1791= Mya pernula Müller, 1779; Recent, North Atlantic.

\section{Nuculana sp.}

Plate 2, fig. 4

Locality: Nita (Basal part of the Middle Formation; Aoki and Nishida, 1999).

Measurements (in $\mathrm{mm}$ ):

\begin{tabular}{ccccc}
\hline Sample No. & valve & Length & La & Plate \\
\hline Aok-004 & left valve & 8.7 & 3.2 & Plate 2, fig. 4 \\
\hline
\end{tabular}

Description: Shell small, long-ovate, inflated, nearly veneriform. Escutcheon is obscure. Umbo located at nearly anterior margin. Strong concentric regular growth line presents on surface. Hinge structure unknown.

Remarks: Shell form and only growth line are observed on surface. However, hinge structure is unknown. Therefore, the author assigns this taxon as Nuculana sp. until well-preserved specimens are studied.

Genus Yoldia Möller, 1842

Type species: Yoldia hyperbore Torell, 1859= Nucula hyperborea Gould, 1841; Recent, North Atlantic.

\section{Yoldia sp.}

Plate 2, figs. 5-6

Locality: Nita (Basal part of the Middle Formation;
Aoki and Nishida, 1999).

\begin{tabular}{|c|c|c|c|c|c|c|}
\hline Sample No. & valve & Length & $\mathrm{La}$ & Height & $\begin{array}{l}\text { Height/ } \\
\text { Length }\end{array}$ & Plate \\
\hline Aok-005 & right valve & 13.7 & 3.2 & 10.1 & 0.74 & Plate 2, fig. 5 \\
\hline Aok-006 & left valve & 14.9 & 5.0 & 8.2 & 0.55 & Plate 2, fig. 6 \\
\hline
\end{tabular}

Description: Shell small, long-ovate, anterior margin rounded, anterior side slightly shorter than posterior side. Postero-dorsal corner pointed. Postero-dorsal border concaved. Strong concentric regular growth line is observed on surface. Hinge structure and escutcheon are unknown.

Remarks: Shells are deformed, umbo area structures cannot be observed. Therefore, the author assigns this taxon as Yoldia sp.

Unidentified species

Plate 2, fig. 6

Locality: Nita (Basal part of the Middle Formation; Aoki and Nishida, 1999).

Measurements (in $\mathrm{mm}$ ):

\begin{tabular}{ccccc}
\hline Sample No. & valve & Length & La & Plate \\
\hline GK-L12005 & left valve & $42.1+$ & 13.2 & Plate 2, fig. 6 \\
\hline
\end{tabular}

Description: Shell moderate, elongated, anterior margin rounded, ventral margin slightly arcuated. Posterior dorsal margin is straight. Strong concentric regular growth line presents on surface. Hinge structure is unknown. Therefore, it will be necessary to describe more details in the future based on well-preserved specimens whose structures can be observed.

Class Bivalvia Linnaeus, 1758

Order Mytiloida Férussac, 1822

Family Mytilidae Rafinesque, 1815

Subfamily Bathymodiolinae Kenk and Wilson, 1985 Genus Bathymodiolus Kenk and Wilson, 1985

Type species: Bathymodiolus thermophilis Kenk and Wilson, 1985; Recent, Galapagos Rift zone.

\section{Bathymodiolus sp.}

Plate 3, figs. 1-6

Locality: Fukusaki Limestone (Upper part of the Lower Formation). 
Measurements (in $\mathrm{mm}$ ):

\begin{tabular}{cccccc}
\hline Sample No. & valve & Length & La & Height & Plate \\
\hline GK-L12006 & right valve & 36 & 1.3 & - & Plate 3, fig. 1 \\
GK-L12007 & right valve & $38.1+$ & 4.6 & 21.8 & Plate 3, fig. 2 \\
GK-L12008 & right valve & 41.5 & - & - & Plate 3, fig. 3 \\
GK-L12009 & left valve & $29.5+$ & - & 17.7 & Plate 3, fig. 4 \\
GK-L12010 & right valve & $46.7+$ & - & - & Plate 3, fig. 5 \\
GK-L12011 & left valve & $33.0+$ & - & 17.5 & Plate 3, fig. 6 \\
\hline
\end{tabular}

Description: The largest one reaches about $47 \mathrm{~mm}$ in length, although the present specimen is broken at anterior, posterior, and dorsal sides. All the specimens are imperfect and height/length ratio and width/length ratio unknown. Shell rather thick and solid, modioliform, inflated, elliptical equivalve. Umbo subterminal, prosogyrated at nearly anterior margin. Anterior margin is located slightly forward than umbo. Anterior margin rounded, dorsal margin convex, postero-dorsal corner rounded, posterior margin broadly rounded, ventral margin straight. Feeble radial threads present in mid-portion. Inner structures are unknown.

Remarks: This species resembles Bathymodiolus platifrons, B. japonicus and B. hirtus described by Hashimoto and Okutani (1994) and Okutani et al. (2004) from Japanese waters. However, this species is distinguished from the similar taxa listed above based on umbo projection from anterior margin, strait ventral margin, as well as shell length of $50 \mathrm{~mm}$. Nobuhara et al. (2008) indicated that bathymodiolin became large in the middle Miocene. However, this species is $50 \mathrm{~mm}$ in shell length. It may be necessary in the future to discuss about the possibility of erecting this taxon as a new species.

Genus Adipicola Dautzenberg, 1927

Type species: Myrina denhami Adams and Adams, 1854 =Modiolus pelagica Woodward, 1854 (by monotypy); Recent, South Atlantic.

\section{Adipicola sp.}

Plate 3, fig. 7

Locality: Kanoura (Lower part of the Middle Formation).

Measurements (in $\mathrm{mm}$ ):

\begin{tabular}{ccccccc}
\hline Sample No. & valve & Length & La & Height & $\begin{array}{c}\text { Height/ } \\
\text { Length }\end{array}$ & Plate \\
\hline GK-L12012 & right valve & 37.4 & 11.2 & 14 & 0.37 & Plate 3, fig. 7
\end{tabular}

Description: Shell small (length: $37.4 \mathrm{~mm}$ ), elongate quadrangular, ligament external. Antero-postero dorsal margin nearly straight. Anterior margin slightly narrow, rounded, posterior margin smoothly rounded, ventral margin slightly concave. Umbo directed forwards, situated at between anterior about one and third. Growth line distinct at posterior margin of shell.

Remarks: Bivalves belonging to genus Adipicola are known as whale-fall community of the present or the past (Amano and Little, 2005; Dell, 1995; Okutani et al., 2004; Tsuchida and Tabakotani, 1997). Okutani and Miyazaki (2007) described Benthomodiolus geikotsucola from deep sea floor of the northeast Pacific. This species closely resembles Adipicola pacifica. However, the calcareous shell has not been preserved and thus the inner structure cannot be observed. This species occurred from the mudstone around Kanoura Limestone which is the authigenic cold-seep carbonate. Consequently, in this study, the author assigns this taxon as Adipicola sp. until wellpreserved specimens with structures are studied.

Class Bivalvia Linnaeus, 1758

Order Veneroida Adams and Adams, 1856

Superfamily Glossaceae Gray, 1847

Family Vesicomyidae Dall and Simpson, 1901

Genus Calyptogena Dall, 1891

Type species: Calyptogena pacifica Dall, 1891 (by monotypy); Recent, East Pacific.

\section{Calyptogena sp. A}

Plate 4, figs. 1-4, Plate 5, figs. 1-6, Plate 6, figs. 1-4

Locality: Kanoura Limestone (Lower part of the Middle Formation), Tanohama Limestone (Upper part of the Lower Formation) and mudstone around Kanoura Limestone (Lower part of the Middle Formation).

Measurements (in mm):

\begin{tabular}{cccccccc}
\hline Sample No. & valve & Length & La & Height & $\begin{array}{c}\text { Height/ } \\
\text { Length }\end{array}$ & Width & Plate \\
\hline GK-L12013 & left valve & 41.9 & 6.9 & 16.5 & 0.39 & - & Plate 4, fig. 1 \\
Aok-007 & right valve & $40.3+$ & 9.6 & - & - & - & Plate 4, fig. 2 \\
Aok-008 & left valve & $39.0+$ & - & 13.2 & - & - & Plate 4, fig. 3 \\
GK-L12014 & right valve & $44.4+$ & - & - & - & - & Plate 4, fig. 4 \\
GK-L12015 & right valve & 45.4 & 6.1 & 18.2 & - & 13.2 & Plate 5, figs. 1, 2 \\
GK-L12016 & left valve & 35.3 & 5.1 & 15.3 & 0.43 & - & Plate 5, figs. 3, 4 \\
GK-L12017 & right valve & $32.7+$ & 4.9 & 17.3 & - & - & Plate 5, fig. 5 \\
GK-L12018 & right valve & $37.9+$ & - & 15.5 & - & - & Plate 5, fig. 6 \\
GK-L12020 & right valve & 37.3 & 8.5 & - & - & - & Plate 6, fig. 1 \\
GK-L12021 & left valve & $37.5+$ & 6.5 & 11.3 & - & - & Plate 6, fig. 2 \\
GK-L12022 & left valve & $36.9+$ & - & 9.1 & - & - & Plate 6, fig. 3 \\
GK-L12023 & left valve & 46.5 & 6.3 & 11.3 & - & - & Plate 6, fig. 4 \\
\hline
\end{tabular}

Description: The largest one can be measured about $47 \mathrm{~mm}$ in length, although it is deformed. Shell thick, not so inflated, elongated slightly inequivalve. 
Ligament external. Anterior margin rounded, ventral margin strait. Posterior margin slightly broad, smoothly rounded. Postero-dorsal margin nearly straight. Umbo low, reaching slightly above hinge line and is located at between anterior about one sixth of valve length. Hinge structures are unknown.

\section{Calyptogena sp. B}

Plate 4, figs. 5-6, Plate 5, figs.7-8, Plate 6, fig. 5

Locality: Kanoura Limestone (Lower part of the Middle Formation), Tanohama Limestone (Upper part of the Lower Formation) and mudstone around Kanoura Limestone (Lower part of the Middle Formation)

Measurements (in $\mathrm{mm}$ ):

\begin{tabular}{ccccccc}
\hline Sample No. & valve & Length & La & Height & Width & Plate \\
\hline Aok-009 & right valve & $51.1+$ & 7.5 & 15.5 & 8.5 & Plate 4, fig. 5, 6 \\
\hline GK-L12019 & right valve & $32.1+$ & 4.2 & 12.4 & 8.5 & Plate 5, fig. 7, 8 \\
\hline GK-L12024 & right valve & 43.9 & 5 & - & - & Plate 6, fig. 5 \\
\hline
\end{tabular}

Description: The largest one can be measured about 51 $\mathrm{mm}$ in length, although posterior end is not observed. Shell rather thick, antero-posteriorly significantly elongated, inequilateral slightly inequivalve. Ligament is external along dorsal side. Anterior margin rounded, ventral margin long, rather strongly concave centrally. Anterior dorsal margin descending at an angle of about $30^{\circ}$ from umbo. Umbo quite low, reaching slightly above hinge line and located at anterior side and one seventh of valve length. Hinge structure is unknown.

Remarks on Calyptogena spp.: In Japan, many fossil species and present species of Calyptogena are described thus far (Amano and Kiel, 2006; Kanno et al., 1998; Métivier et al., 1986; Kojima and Ohta, 1997; Kuroda, 1943; Okutani, 1957, 2000, 2008; Okutani and Métivier, 1986; Okutani et al., 1992, 1993, 1996, 1997, 2000, 2002).

Calyptogena sp. A closely resembles Calyptogena (Archivesica) similaris described by Okutani et al. (1997). However, there are differences in that Calyptogena sp. A of shell length is a half size or less and anterior margin and antero-dorsal margin are rounded. Adulomya cf. uchimuraensis reported by MITI (1972) is long as $150 \mathrm{~mm}$ (Kanno et al., 1998). And Calyptogena sp. A is more elongated than C. akanudaensis. Therefore, this species is different from these two species. This species closely resembles Adulomya hokkaidoensis in shell length and form, which is described by Amano and Kiel (2006) from the Miocene Chikubetsu Formation as a part of whale-fall community. However, Adulomya hokkaidoensis is known only from the whale-fall community. However, hinge structure of Calyptogena sp. A cannot be observed. Consequently, in this study, the author assigns this taxon as Calyptogena sp. A. Most of fossil bivalves from mudstone around Kanoura Limestone are considered as this species, although they are deformed.

Calyptogena sp. B resembles the modern species Calyptogena (Ectenagena) phaseoliformis. However, Calyptogena sp. B is distinguished from the thick shell and $50 \mathrm{~mm}$ or less in shell length. Adulomya uchimuraensis is different from this species because that ventral margin is straight or only a little concave toward dorsal. It is considered that this species is the same as that occurred from mudstone, but the specimen is significantly deformed. Hinge structure cannot be observed. Therefore, in this study, the author assigns this taxon as Calyptogena sp. B.

\section{Conclusions}

The middle part of the Neogene Taishu Group including the cold-seep carbonates was originated from the authigenic chemosynthetic fossil molluscan faunas, which are distributed in Tsushima Islands, Nagasaki Prefecture. It is considered that the Taishu Group was deposited in deep sea environments of greater than $500 \mathrm{~m}$ depth. In this paper, the author classified the bivalves from the cold-seep carbonates and mudstones. The assemblages are identified as ten species belonging to seven genera as follows: Bathymodiolus sp., Adipicola sp., Calyptogena spp., Acharax spp., Acila sp., Nuculana sp., and Yoldia sp. These fossil bivalves may be considered to be new species pending on further studies. It will be necessary in the future to classify them based on detailed hinge structures of well-preserved specimens.

\section{Acknowledgements}

The author is grateful to Mr. Takahiro Aoki (Shinwa Techno Co., Ltd.) for lending many specimens from his collections. Dr. Shoichi Shimoyama (Kyushu University) is gratefully acknowledged for providing helpful advice and suggestions. Thanks are extended to Dr. Kozo Takahashi (Kyushu University) for providing opportunity to write this manuscript and for his helpful suggestions and improving the English text. The author is also greatly 
indebted to Dr. Tamio Nishida (Professor Emeritus of Saga University), who acted as an external reviewer, for providing valuable comments and suggestions.

\section{References}

Adams, H., and Adams, A. (1853-1859) The genera of Recent Mollusca arranged according to their organization. vol. 1, 484 pp., vol. 2, 660 pp. Publisher John Van Voorst, London.

Amano, K., and Kiel, S. (2006) Fossil vesicomyid bivalves from the North Pacific region. The Veliger, 49, 270293.

Amano, K., and Little, C.T.S. (2005) Miocene whale-fall community from Hokkaido, northern Japan. Palaeogeography, Palaeoclimatology, Palaeoecology, 215, 345-356.

Aoki, T., and Nishida, T. (1999) Chemosynthetic molluscan fauna found from the basal part of the Middle Formation of the Taishu Group. Proceedings of The Nishinihon Branch, Geological Society of Japan, 114, 19-20. (In Japanese)

Baba, K. (1990) Molluscan fossil assemblages of the Kazusa Group, south Kwanto, central Japan. 445 pp, Keio Yochisha. (In Japanese)

Bruguière, J.G. (1789-1816) Encyclopédic méthodique ou par ordre de matières. Histoire naturelle de Vers des Mollusques. 758 pp. Charles Joseph Panckoucke, Paris.

Clark, W. (1851) On the classification of the British marine testaceous Mollusca. The Annals and Magazine of Natural History, sec. 2, 7, 469-481.

Coan, E.V., Scott, P. V., and Bernard, F. R. (2000) Bivalve seashells of western North America. Santa Barbara Museum of Natural History, 764 pp.

Dall, W.H. (1891) Scientific results of explorations by the U. S. Fish Commision Steamaer Albatross. XX. On some new or interesting West American shells obtained from dredgings of the U.S. fish commission streamer Albatross in 1888. Proceedings of the U. S. National Museum, 14, 174-191.

Dall, W.H. (1908) Reports on the dredging operations off the west coast of Central Amarica ... The Mollusca and Brachiopoda. Bulletin of the Museum of Comparative Zoology at Harvard University, 43, 205-487.

Dall, W.H., and Simpson, C.T. (1901) The Mollusca of Porto Rico. Bulltin of the U. S. Fish and Fisheries Commision, 20, 351-524.

Dautzenberg, P. (1927) Mollusques provenant des campagnes scientifiques du Prince Albert Ier de Monaco dans l'Ocean Altantique et dans le Golfe de Gascogne. Résultats des Campagnes Scientifiques accomplies par Albert Ier, 72, 1-400.

Dell, R.K. (1995) New species and records of deep-water mollusca from off New Zealand. Tuhinga (Records of the Museum of New Zealand Te Papa Tongarewa), 2, 1-26.

Férrusac, A.E.de. (1822) Tableaux systématiques des animaux mollusques. Classés en families naturelles, dans lequels on a établi la concordance de tous les systémes; suivis d'un prodrome general pour tous les mollusques terrestres ou fluviatiles, vivants ou fossils. $111 \mathrm{pp}$. Berntland, Paris.

Gould, A.A. (1841) Reports on the Invertebrate of Massachusetts, comprising the Mollusca, Crutacea, Annelida and Radiata. 373 pp. Cambridge, Folsom, Wells and Thurston.

Gray, J.E. (1840) Synopsis of the Contents of the British Museum. 370 pp. G. Woodfall, London.

Gray, J.E. (1847) A list of the genera of Recent Mollusca, their synonyma and types. Proceedings of the Zoological Society of London, 15, 129-219.

Hashimoto, J., and Okutani, T. (1994) Four new species mytilid mussels associated with deep-sea chemosynthetic communities around Japan. Venus (Japanese Journal of Malacology), 53, 61-83.

Hatai, K., and Koike, K. (1957) On fossil mollusca from Chiba Prefecture, Japan. Japanese Journal of Geology and Geography, 28, 77-90.

Hinds, R.B. (1843) Descriptions of new species of Nucula, from the collections of Captain Sir Edward Belcher, during the years 1836-42. Vol. 2, Mollusca, 72 pp. Smith, Elder and Co., London.

Ibaraki, M. (1994) Ages and paleoenvironments of Tertiary in northwestern Kyushu the view point of planktonic foraminifer assemblages. The Earth Monthly (Gekkan Chikyu), 16, 150-153. (In Japanese)

Kamada, Y. (1962) Tertiary marine Mollusca from the Joban coal-field, Japan. Special Papers, Paleontological Society of Japan, 8, 1-187.

Kanehara, K. (1937) On some Tertiary fossil shells from Hokkaido (Yesso). Japanese Journal of Geology and Geography, 14, 155-161. (In Japanese)

Kanie, Y., and Kuramochi, T. (1995) Acharax yokosukensis n. sp. (gigantic Bivalve) from the Miocene Hayama Formation of the Miura Peninsula, south-central Japan. Science Report of Yokosuka City Museum, (43), 51-57. 
Kanie, Y., Kuramochi, T., Asami, S., and Kanno, S. (1995) Solemyid pelecypod of Miocene Hayama Group in Miura Peninsula. Report of Culture and Natural Treasury, Yokosuka City, (29), 57-61. (In Japanese)

Kanie, Y., Kuramochi, T., Kanno, S., Mizota, C., Shimizu, M., and Takakuwa, Y. (1999) New occurrence and shell from of Middle Miocene Acharax gigas (Bivalvia: Solemyidae) in Gunma Prefecture. Bulletin of Gunma Museum Natural History, (3), 17-23. (In Japanese with English abstract)

Kanno, S. (1960) The Tertiary System of the Chichibu Basin, Saitama Prefecture, central Japan. Part 2. Paleontology, 123-196. Japanese Society Promotion Science.

Kanno, S., Tanaka, K., Koike, K., Narita, K., and Endo, T. (1998) Adulomya uchimuraensis Kuroda (Bivalvia) from the Miocene Bessho Formation in Shiga-mura, Nagano Prefecture, Japan. Research Report of the Shinshu- shinmachi Fossil Museum, 1, 17-28.

Kenk, V.C., and Wilson, B.R. (1985) A new mussel (Bivalvia, Mytilidae) from hydrothermal vents in the Galapagos Rift zone. Malacologia, 26, 253-271.

Kojima, S., and Ohta, S. (1997) Calyptogena okutanii n. sp., a sibling species of Calyptogena soyoae Okutani, 1957 (Bivalvia: Vesicomyidae). Venus (Japanese Journal of Malacology), 56, 189-195.

Kuroda, T. (1943) Akebiconcha, a new pelecypod genus. Venus (Japanese Journal of Malacology), 13, 14-18. (In Japanese with English description)

Link, H.F. (1806-1808) Beschreibung der Naturalian. 1, 160 p., 2, 30 pp., 3, 38 pp. Sammlung der Universität zu Rostock, Rostock.

Linnaeus, C. (1758) Systema naturae per regna tria naturae, secundum classes, ordines, genera, species, cum characteribus, diffrentiis, synonymis, locis. Tomus 1, edition decimal, reformata, 824 pp. Laurentius Salvius, Stockholm.

Masuda, K. (1970) Molluscan fauna from the Taishu Group, Tsushima Islands, Nagasaki Prefecture, Japan. Memoirs of Natural Science Museum Tokyo, 3, 25-32

Matsumoto, T. (1969) Geology of Tsushima and Relevant Problems. Memoirs of Natural Science Museum Tokyo, 2, 4-18. (In Japanese with English abstract)

Métivier, B. Okutani, T., and Ohta, S. (1986) Calyptogena (Ectenagena) phaseoliformis n. sp., an unusual vesicomyid bivalve collected by the submersible Nautil from abyssal depths of the Japan and Kurile Trenches. Venus (Japanese Journal of Malacology), 45, 161-168.

MITI (The Ministry of International Trade and Industry) (1972) Report on the regional geological survey, Tsushima, Kamiagata district of the 1971' fiscal year. pp. 29. (In Japanese)

MITI (The Ministry of International Trade and Industry) (1972) Report on the regional geological survey, Tsushima, Kamiagata district of the 1972' fiscal year. pp. 34. (In Japanese)

MITI (The Ministry of International Trade and Industry) (1973) Report on the regional geological survey, Tsushima, Kamiagata district of the 1973' fiscal year. pp. 52. (In Japanese)

Möller, H. (1842) Index Molluscorum Groenlandiae. Naturhistorisk Tidsskrft, 4, 76-97.

Müller, O.F. (1779) Von zwoen wenig bekannten Muscheln, der Schinkenarche und der gerunzeltenMahlermuschel. Beschäftigungen der Berlinischen Gesellschaft naturforschender Freunde, 4, 55-59.

Nakajo, T., and Funakawa, T. (1996) Eocene radiolarians from the Lower Formation of the Taishu Group. Journal of Geological. Society of Japan, 102, 751-754 (In Japanese)

Nakajo, T., and Maejima, W. (1998) Morpho-dynamics development and facies organization of the Tertiary delta system in the Taishu Group Tsushima Islands, southwestern Japan. Journal of Geological. Society of Japan, 104, 749-763.

Nakajo, T., Yamaguchi, Y., Komatsubara, J., and Ohtake, S. (2006) Sedimentation and tectonics of the Tertiary delta to basin successions in the Tsushima Islands, off northwestern Kyushu, Japan. In: Ito, M., Yagishita, K., Ikehara, K. and Matsuda, H. (Eds.), Field Excursion Guidebook, $17^{\text {th }}$ International Sedimentological Congress,Fukuoka, Japan, Sedimentological Society of Japan, FE-B11, 1-12.

Natori, H. (1964) Some molluscan fossils from the Tertiary Muro Group in Kii Peninsula, Japan. Transctions and Proceedings of the. Palaeontological Socity of Japan, New Series, 55, 247-255.

Ninomiya, T., Miyata, Y., Taniguchi, S., Shimoyama, S., Matsuda, H., Yamanaka, T., Aoki, T., and Nishida, T. (2008) Cold-seep carbonates and chemosynthetic assemblages from the Taishu Group, in the Tsushima Islands. Japan Geoscience Union, 2008 Meeting, abstract.

Ninomiya, T., Taniguchi, S., Shimoyama, S., Miyata, Y., Daniel, D. J., Matsuda, H., Yamanaka, T., Aoki, T., Nishida, T., and Ichihara, T. (2010) Sedimentary environment of the Neogene Taishu Group, Nagasaki Prefecture, Southwest Japan. Annual Meeting of Geological Society of Japan, p. 68. (In Japanese)

Nobuhara, T., Imaizumi, I., Kaneko, T., Koike, H.,Narita, K., and Amano, K. (2008) Btahymodiolin bivalves from the Middle Miocene cold-seep carbonate in Bessho Formation, Nagano Prefecture. Abstracts with Programs The 157th Regular Meeting, the Palaeontological Society of Japan, p. 30. (In Japanese) 
Okada, H., and Fujiyama, I. (1970) Sedimentation of the Taishu Group, in the Shiohama Area, Central Tsushima, Kyushu. Memoirs of Natural Science Museum Tokyo, 3, 9-21. (In Japanese with English abstract)

Okutani, T. (1957) Two new species of bivalves from deep water in Sagami Bay by the R. V. Soyo-Maru. Bulletin of the Tokai Regional Fisheries Research Laboratory, 17, 27-30.

Okutani, T. (2000) Vesicomyidae. In: Okutani, T. (Ed.), Marine Mollusks in Japan. Tokai University Press, Tokyo, 996999.

Okutani, T. (2008) Mollusca. In: Fujikura, K., Okutani, T. and Maruyama, T. (Eds.), Deep-sea Life-Biological observations using research submersibles. Tokai University Press, Tokyo, 99-142. (In Japanese)

Okutani, T., and Miyazaki, J. (2007) Benthomodiolus geikotsucola n. sp.: a mussel colonizing deep-sea whale bones in the northwest Pacific (Bivalvia: Mytilidae). Venus (Japanese Journal of Malacology), 66, 49-55.

Okutani, T., and Métivier, B. (1986) Descriptions of three new species of vesicomyid bivalves collected by submersible Nautile from abyssal depths off Honshu, Japan. Venus (Japanese Journal of Malacology), 45, $147-160$

Okutani, T., Kojima, S., and Ashi, J. (1996) An unusual vesicomyid bivalve, Calyptogena nankaiensis n. sp. from bathyal depth off Honshu, Japan. Venus (Japanese Journal of Malacology), 55, 257-263.

Okutani, T., Kojima, S., and Ashi, J. (1997) Further discovery of a new taxon of vesicomyid clam, Nankai Trough, off Honshu, Japan. Venus (Japanese Journal of Malacology), 56, 185-188.

Okutani, T., Kojima, S., and Iwasaki, N. (2002) New and known vesicomyid bivalves recently collected from the western and central Nankai Trough off Shikoku and Honshu, by deep sea research systems of Japan Marine Science and Technology Center. Venus (Japanese Journal of Malacology), 61, 129-140.

Okutani, T., Fujikura, K. and Hashimoto, J. (1993) Another new species of Calyptogena (Bivalvia: Vesicomyidae) from the bathyal depth in Suruga Bay, Japan. Venus (Japanese Journal of Malacology), 52, 121-126.

Okutani, T., Fujikura, K., and Kojima S. (2000) New taxa and review of vesicomyid bivalves collected from the northwest Pacific by deep sea research systems of Japan Marine Science and Technology Center. Venus (Japanese Journal of Malacology), 59, 83-101.

Okutani, T., Fujikura, K. and Sasaki, T. (2004) Two new species of Bathymodiolus (Bivalvia: Mytilidae) from methane seeps on the Kuroshima Knoll off the Yaeyama Islands, southwestern Japan. Venus (Japanese Journal of Malacology), 62, 97-110.

Okutani, T., Fujiwara, Y., Fujikura, K., Miyake, H., and Kawato, M. (2004) A mass aggregation of the mussel Adipicola pacifica (Bivalvia: Mytilidae) on submerged whale bones. Venus (Japanese Journal of Malacology), 63, 61-64.

Okutani, T., Hashimoto J., and Fujikura, K. (1992) A new species of vesicomyid bivalve associated with hydrothermal vents near Amami-Ohshima Island, Japan. Venus (Japanese Journal of Malacology), 51, 225233.

Otofuji, Y., and Matsuda, T. (1983) Paleomagnetic evidence for the clockwise rotation of Southwest Japan. Earth and Planetary Science Letters, 62, 349-359.

Otofuji, Y., and Matsuda, T. (1987) Amount of clockwise rotation of Southwest Japan-fan shape opening of the southwestern part of the Japan Sea. Earth and Planetary Science Letters, 85, 289-301.

Rafinesque, C.S. (1815) Analyse de la nature ou tableau de l'univers et des corps organisés. 224 pp. Barravecheia, Palermo.

Sakai, H., and Yuasa, T. (1998) K-Ar Ages of the Mogi and Ugetsuiwa Subaqueous Pyroclastic Flow Deposits in the Taishu Group, Tsushima Islands. Memoirs of Natural Science Museum Tokyo, 31, 23-28

Sasaki, T., Okutani, T., and Fujikura, K. (2005) Molluscs from hydrothermal vents and cold seeps in Japan: A review of taxa recorded in twenty recent years (1984-2004). Venus (Japanese Journal of Malacology), 64, 87-133.

Takahashi, K., and Nishida, T. (1974) On the molluscan fossils from the Lower Formation of the Taishu Group in the Kamiagata district of Tsushima Islands. Bulletin of Faculty of Liberal Arts, Nagasaki University. Natural science, 15, 15-21. (In Japanese with English abstract)

Torell, O.M. (1859) Bidrag till Spitsbergen Mollusk-fauna. Jemte en allman oversigt af Arktiska regionens naturforahallanden och forntida ubtredning, $154 \mathrm{pp}$. Boktrycheri, Stocholm.

Tsuchida, E., and Tabakotani, Y. (1997) Deep-sea mytilid bivalve assemblage on whale bone collected from the entrance of Tokyo Bay. Venus (Journal of Malacological Society of Japan), 56, 77-78. (In Japanese)

Woodward, S.P. (1851-1856) A manual of the Mollusca; or a rudimentary treatise on Recent and fossil shells, 486 pp. John Weale, London.

Yamaguchi, Y., and Oho, Y. (2007) Sedimentological history of Tertiary slope facies in the northern area of the Tsushima Islands, Japan. Journal of Geological Society of Japan, 113, 113-126. (In Japanese with English abstract) 
Plate 1

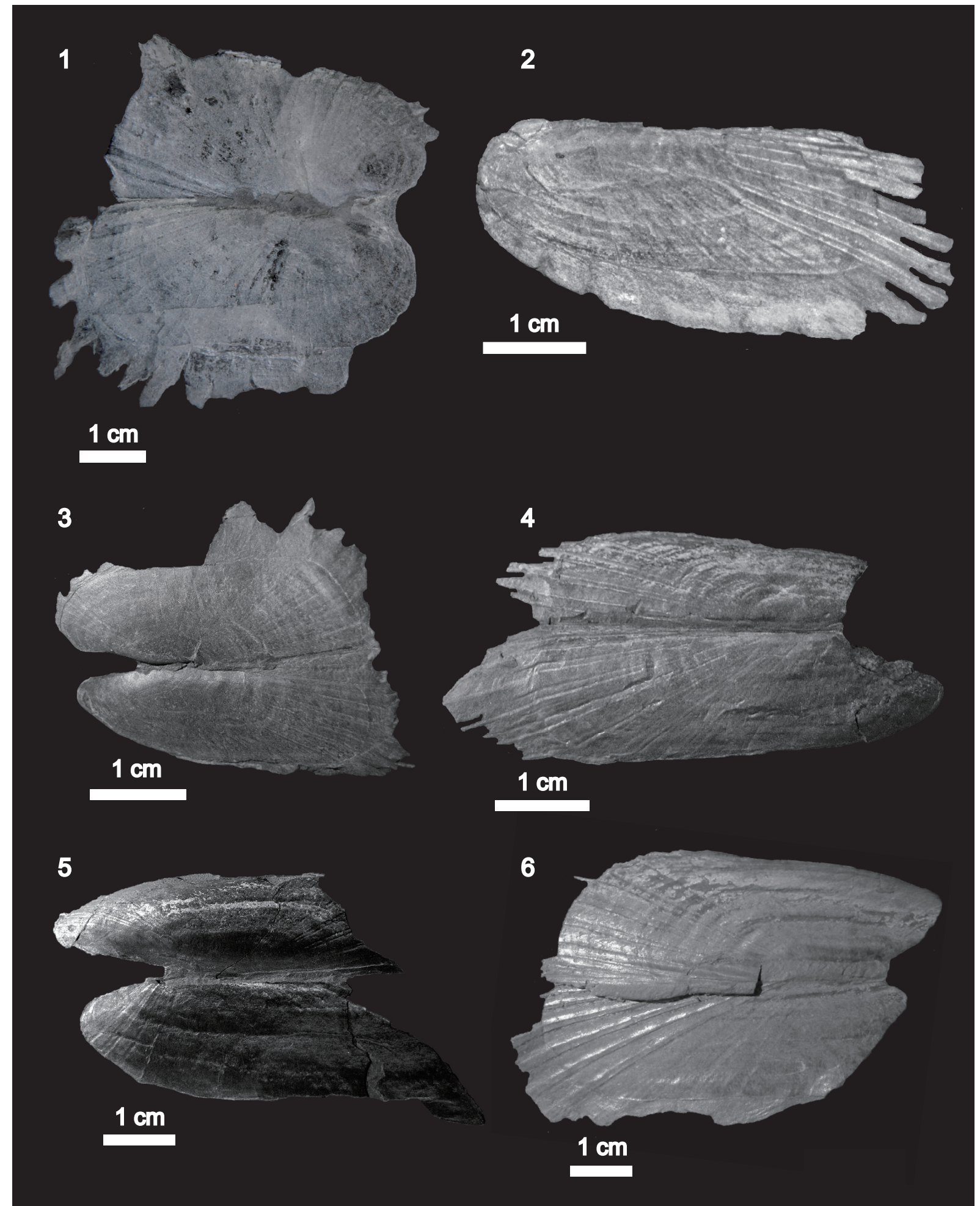

Plate 1. 1-6. Acharax spp. from Nita (fig. 1: Acharax sp. A [Sample ID: Aok-001]; fig. 2: Acharax sp. B [Aok-002]; fig. 3: Left valve of Acharax sp. B [GK-L12000]; fig. 4: Acharax sp. B [Aok-003]; figs. 5, 6: Acharax sp. B [GK-L12001], fig. 5: Anterior side; fig. 6: Posterior side). 
Plate 2

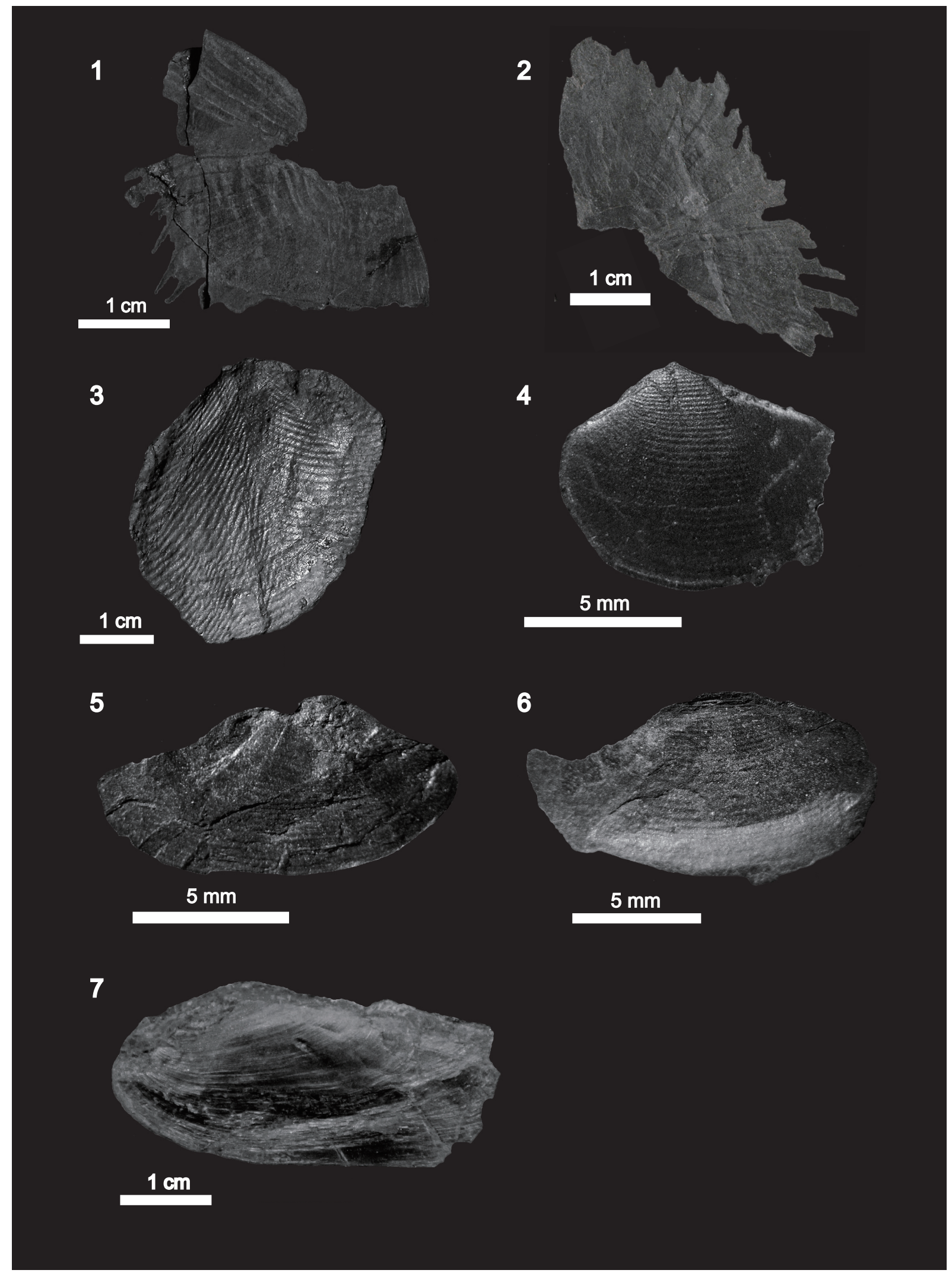

Plate 2. 1, 2. Acharax sp. C from Kanoura (fig. 1: Acharax sp. C [GK-L12002]; fig. 2: Acharax sp. C [GK-L12003]), 3. Acila sp. from Fukusaki [GK-L12004], 4-7. Nuculanidiae, Unidentified species from Nita (fig. 4: Left valve of Nuculana sp. [Aok-003]; fig. 5: Right valve of Yoldia sp. [Aok-004]; fig. 6: Right valve of Yoldia sp. [Aok-005]; fig. 7: Unidentified species [GK-L12005]). 
Plate 3

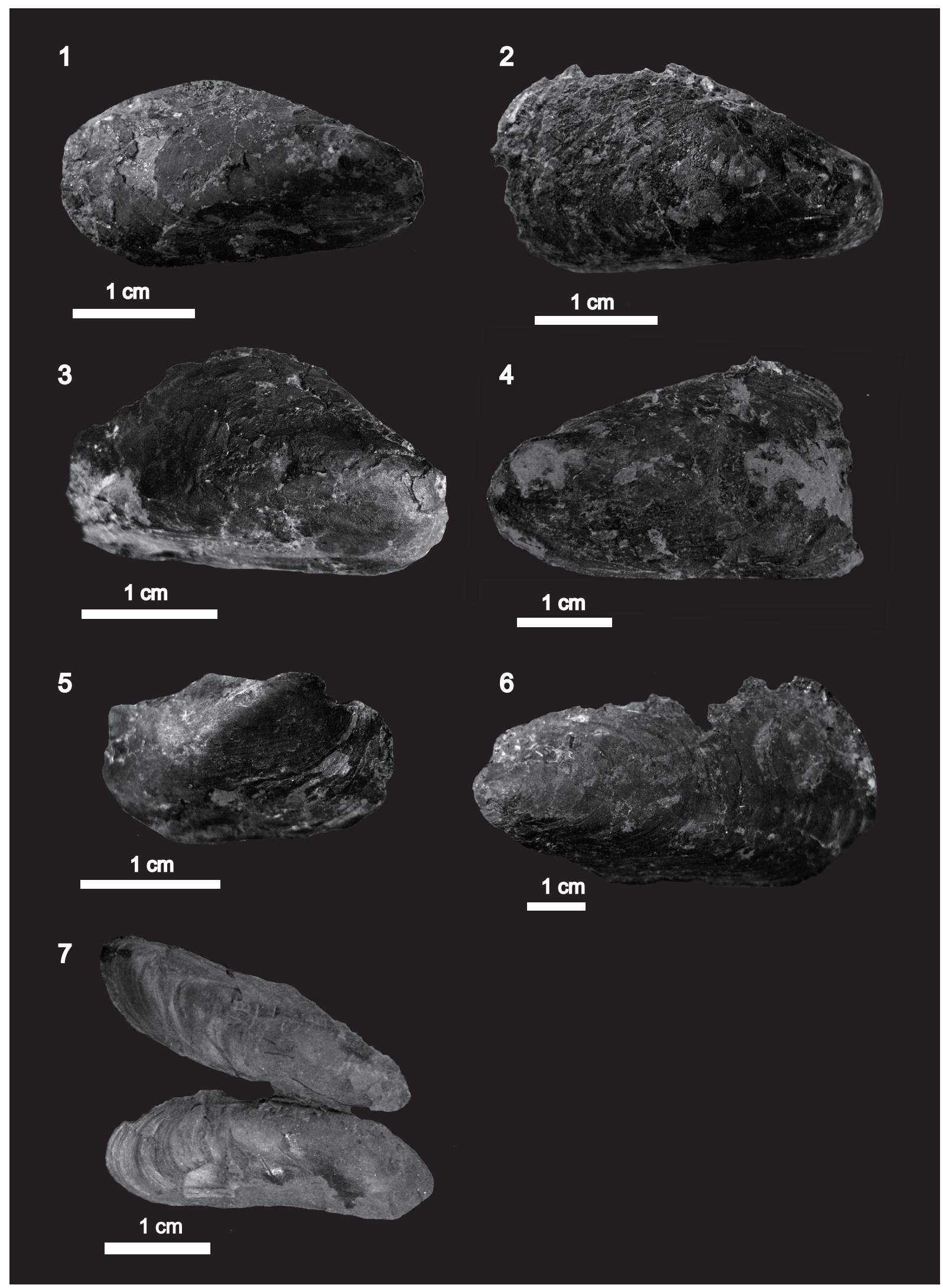

Plate 3. 1-6. Bathymodiolus sp. from Fukusaki Limestone (fig. 1: Right valve [GK-L12006]; fig. 2: Right valve [GK-L12007]; fig. 3: Right valve [GK-L12008]; fig. 4: Left valve [GK-L12009]; fig. 5: Right valve [GK-L12010]; fig. 6: Left valve [GK-L12011]]]), 7. Adipicola sp. [GK-L12012]. 


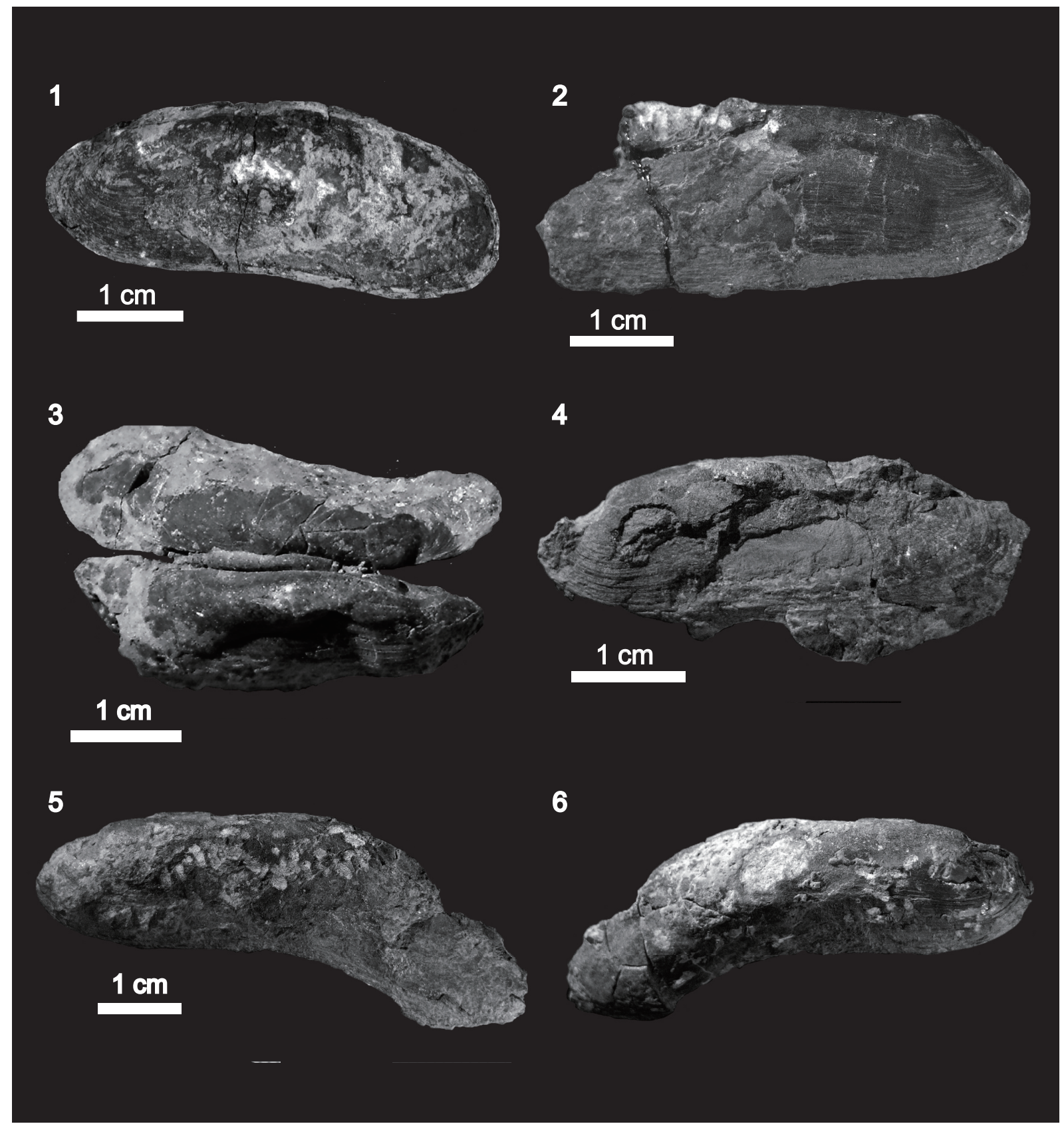

Plate 4. Calyptogena spp. from Kanoura Limestone. 1-4. Calyptogena sp. A (fig. 1: Left valve [GK-L12013]; fig. 2: Right valve [Aok-007]; fig. 3: Dorsal side (Aok-008). fig. 4: Left valve (GK-L12014)), 5, 6. Calyptogena sp. B [Aok-009] (fig. 5: Right valve; fig. 6. Left valve). 


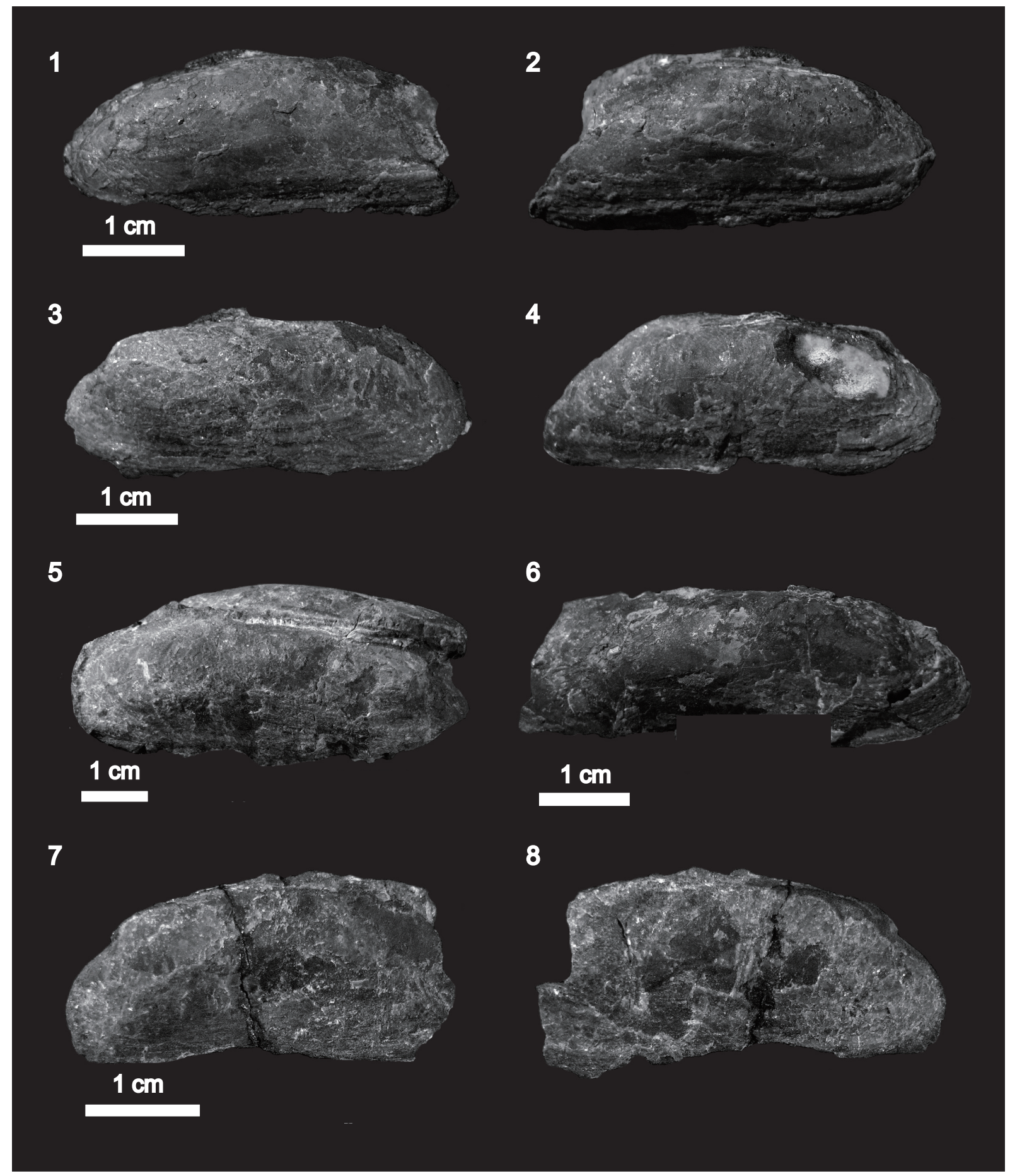

Plate 5. Calyptogena spp. from Tanohama Limestone. 1-6. Calyptogena sp. A. 1, 2. Calyptogena sp. A ([GK-L12015]: fig. 1: Right valve; fig. 2: Left valve), 3, 4. Calyptogena sp. A ([GK-L12016]: fig. 3: Right valve; fig. 4: Left valve), 5. Calyptogena sp. A [GK-L12017]. 6. Calyptogena sp. A [GK-L12018], 7, 8. Calyptogena sp. B ([GK-L12019]: fig. 7: Right valve; fig. 8: Left valve). 
Plate 6

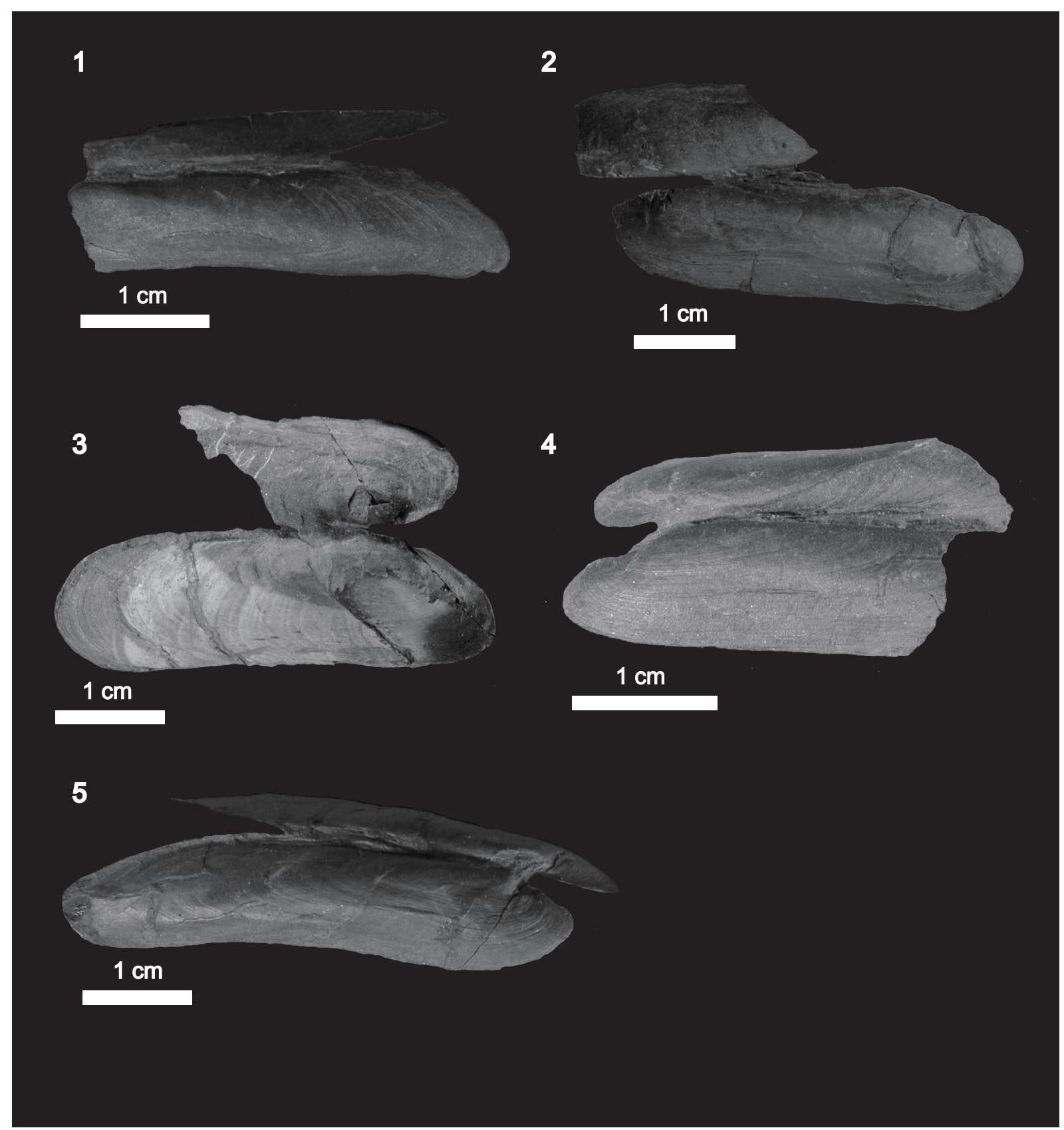

Plate 6. Calyptogena spp. from mudstone around Kanoura Limestone. 1-4. Calyptogena sp. A (fig. 1: Right valve [GK-L12020]; fig. 2: Right valve [GK-L12021]; fig. 3: Left valve Right valve [GK-L12022]; fig. 4: Left valve [GK-L12023]), fig. 5. Left valve of Calyptogena sp. B [GK-L12024]. 